\title{
Radiolarians and Diatoms from the mid-Cretaceous Successions of the Sergipe Basin, Northeastern Brazil: palaeoceanographic Assessment
}

\author{
EDUARDO A.M. KOUTSOUKOS ${ }^{1}$ and MALCOLM B. HART ${ }^{2}$ \\ ${ }^{1}$ Petróleo Brasileiro S.A. (PETROBRAS) - CENPES, Cidade Universitária, Q.7, CEP: 21910, Ilha do Fundão, Rio de Janeiro, \\ Brazil. \\ ${ }^{2}$ Department of Geological Sciences, POLYTECHNIC SOUTH WEST, Plymouth, PL4 8AA, Devon, England.
}

\begin{abstract}
Radiolarians and diatoms are documented for the first time from the midCretaceous succession of the Sergipe Basin, a passive marginal basin in northeastern Brazil. Prevailing palaeoceanographic conditions are inferred for the episodes of siliceous radiolarian and diatom biomineralization/preservation. Radiolarian faunas are first recorded in the middle to upper Albian, from scattered occurrences, and subsequently throughout most of the CenomanianTuronian succession. Spumellarian forms are dominant in all the sections. Nassellarian forms seem to have thrived in relatively deep-water environments, in middle neritic to upper bathyal pelagic biotopes, and have been recovered from upper Albian and uppermost Cenomanian to middle Turonian sediments. Diatom frustules are only recorded from upper Cenomanian and lower Turonian deposits. These seem to have been more abundant in shallower neritic environments. The onset of the radiolarian assemblages in middle-late Albian times (with waning low-oxygen pelagic conditions) is thought to be a response to better developed oceanic circulation patterns and to a water mass saturated in dissolved silica, perhaps generated by deepsea volcanic processes in the formation of early oceanic crust and the mid-oceanic ridge in the northern South Atlantic. On the other hand, the record of radiolarian and diatom tests throughout the Cenomanian-Turonian succession is commonly associated with dysaerobic to quasi-anaerobic bottom conditions. This is not only in keeping with high epipelagic primary productivity in welloxygenated surface waters and that the sea water apparently contained a high level of dissolved silica, but also suggests that the bottom and interstitial waters were enriched in carbon dioxide, had a low pH and slightly negative redox-potential (Eh). The overall conditions would have favoured the biomineralization and post-mortem preservation of siliceous organisms increasing, therefore, the radiolaria+diatom/foraminifera ratio in the sediments, which supports the conclusions of several previous authors.
\end{abstract}

\section{INTRODUCTION}

Radiolarians and diatoms are recorded for the first time from the mid-Cretaceous (middle Albian to Turonian) succession of the Sergipe Basin, a passive marginal basin in northeastern Brazil (Figs. 1, 2). Their patterns of distribution and diversity demonstrate a close correspondence with the palaeobathymetry and overall palaeoceanographic conditions (depth-related in part) prevailing during the time on the northwestern margins of the South Atlantic.

The systematics of the radiolarian microfauna studied is documented. Because of the great uncertainty regarding the systematic positions of diatom frustules recovered during this study, a taxonomic listing of species is not attempted. Rather, the microflora is briefly discussed in general informal terms (and arranged in morphotypes). The specimens may be preserved as unaltered siliceous tests and either pyritized (late Aptian radiolarians) or calcified tests, where the original amorphous silica forming the skeleton has been replaced.

\section{Localities and Well-Sections}

All assemblages examined during this study come from
mid-Cretaceous outcrops and oil well-sections in the Sergipe Basin. The sites from which Albian to Turonian radiolarian/ diatom bearing sediments have been recovered are listed in the Appendix (UTM coordinates, local references, lithostratigraphic units) and their location can be found in Fig. 1. All studied Cenomanian-Turonian outcrop sections correspond to localities that were named and documented in full by Bengtson (1983, p. 63-71), to whom the reader is referred for complete locality descriptions. The toponyms and respective locality numbers used here follow the same references given in the above work. Inferred palaeobathymetries of the studied sections were based on the interpretation of the patterns of paleoenvironmental distribution of foraminiferal palaeocommunities and lithofacies and have been documented elsewhere (Mello et al., 1989; Koutsoukos \& Hart, in press; Koutsoukos et al., in press - e.g. see Fig. 3).

The Cenomanian-Coniacian succession (Cotinguiba Formation) has been studied in detail by Bengtson (1983) and Berthou \& Bengtson (1988), who established an ammonite biostratigraphic zonation and investigated the potential of 


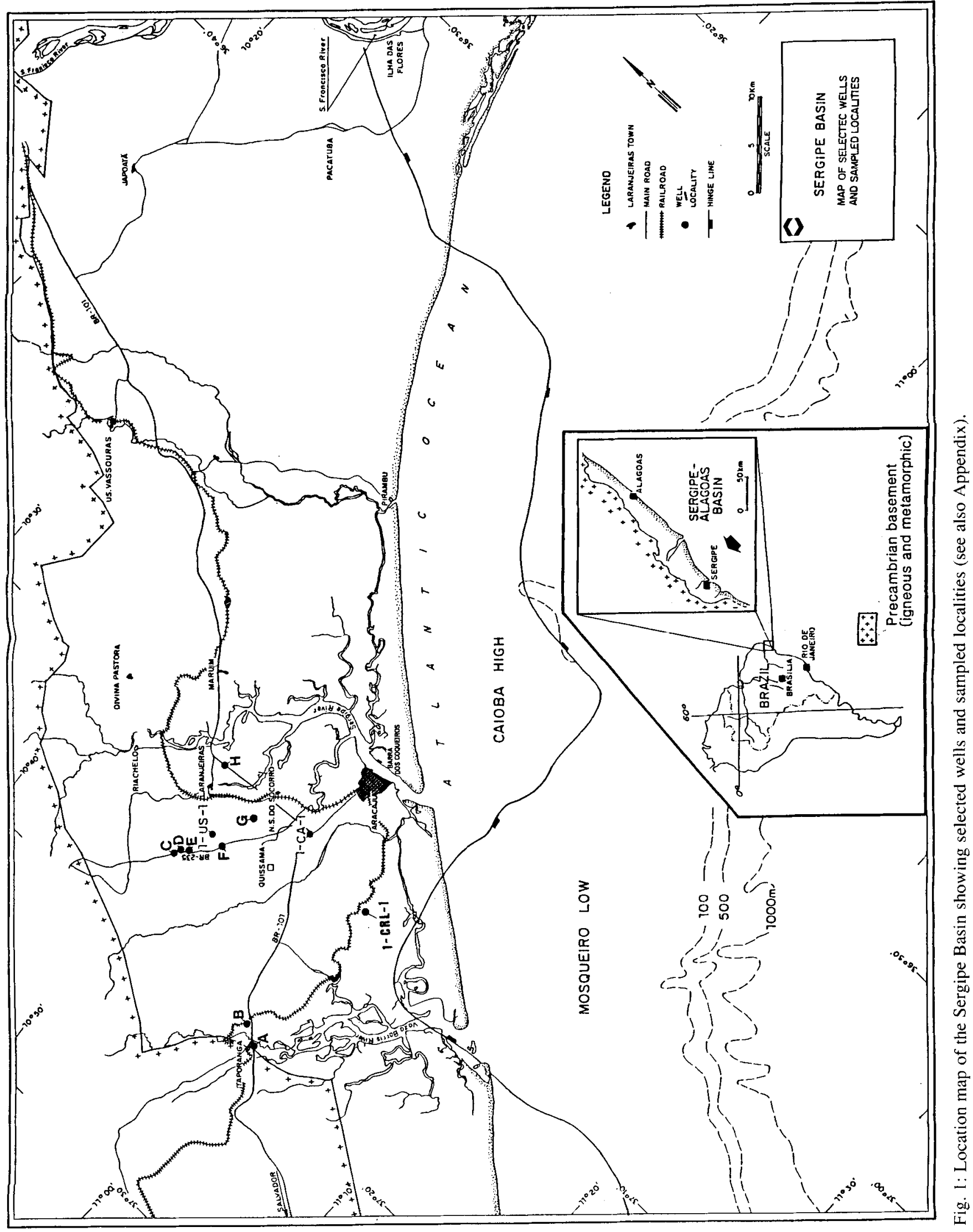




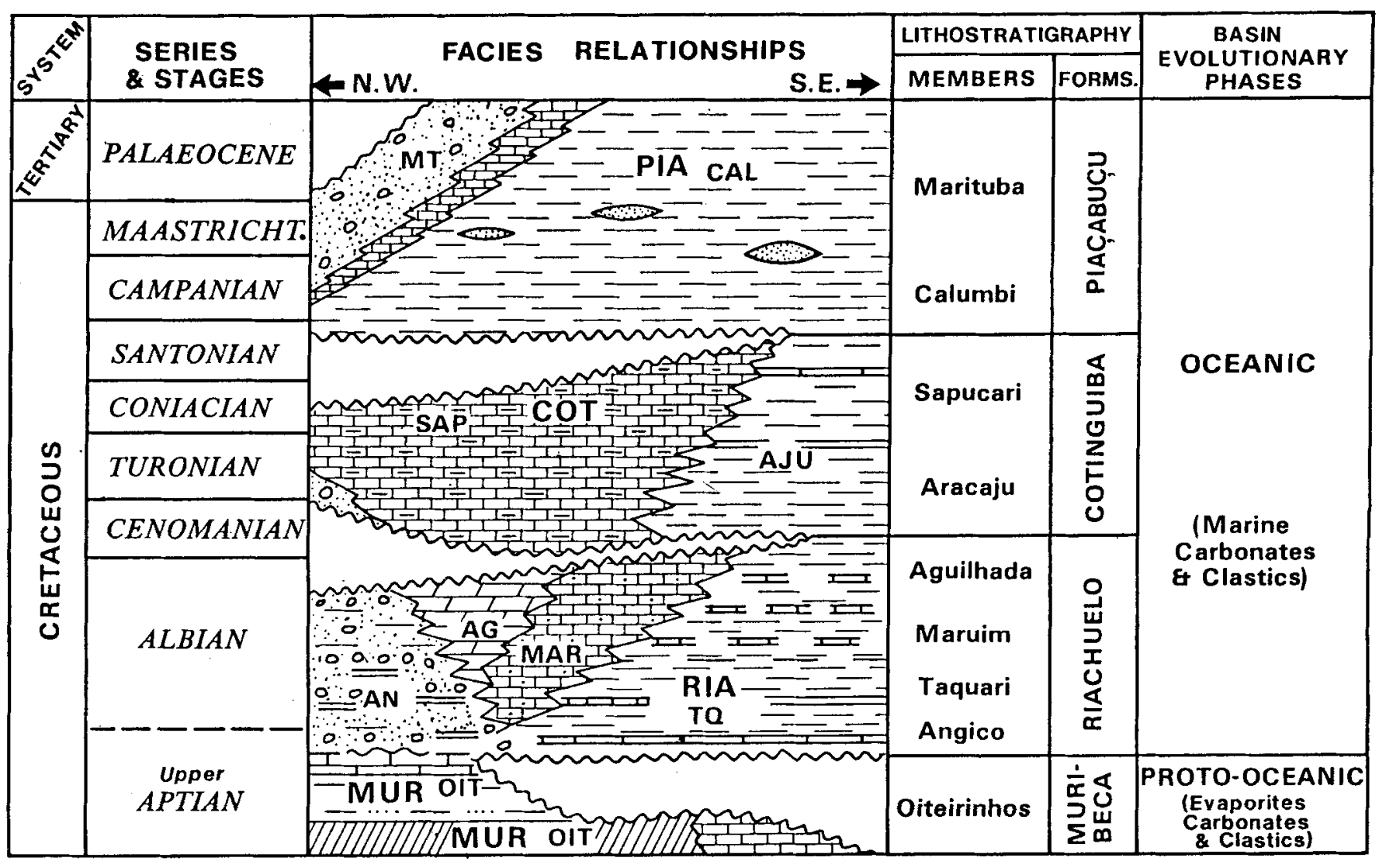

\section{LEGEND}

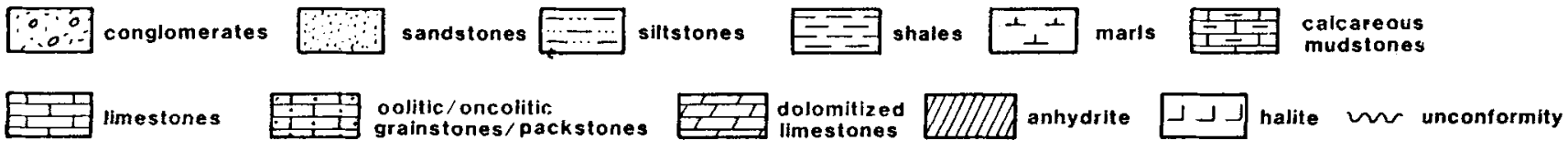

Fig. 2: Middle and Upper Cretaceous lithostratigraphy of the Sergipe basin (based on Ojeda \& Fugita, 1976 and Bengtson, 1983 ). Tectonic evolutionary phases after Asmus \& Baisch (1983). Abbreviations refer to lithostratigraphic units.

microfacies analysis for stratigraphic correlation, respectively. An extensive survey and taxonomic revision has been recently carried out by the present first author on the foraminiferal microfauna recovered from the late Aptian-Maastrichtian succession. The dating of sections is mostly based on an integrated biostratigraphical scheme, currently in preparation, based on foraminifera and ammonites.

\section{Sample Preparation and Deposition of Types}

The studied assemblages were collected as a result of conventional preparation of samples for foraminiferal analysis. Laboratory sample preparation was mostly carried out in the 'Setor de Bioestratigrafia e Paleoecologia' of the PETROBRAS' Research Centre (CENPES), in Rio de Janeiro, Brazil. All the indurated samples were crushed prior to processing. Representative cuts of 60 grams (ditch-cuttings) and 120 grams of sediment (cores and outcrops) were taken from each sample and then immersed into a solution of concentrated hydrogen peroxide, and allowed to sit for about 6-8 hours in a fume cupboard until break down. The disaggregated sediment was then washed through one finemesh sieve of $63 \mu \mathrm{m}$ to eliminate the clay. The residues were allowed to dry and were, subsequently, dry-sieved with three screens of $125 \mu \mathrm{m}, 250 \mu \mathrm{m}$ and $500 \mu \mathrm{m}$ mesh. All size fractions were examined and the microfossils (foraminifera, ostracods, radiolarians, micromolluscs) were picked out on a gridded tray and collected into one-hole slides, until a minimum representative count of approximately 300 specimens was reached.

Samples from a complementary locality (Pati 1) were processed at the laboratories of the Department of Geological Sciences of Polytechnic South West, Plymouth, in a standard manner as follows. Samples were broken down into small pieces using a mortar and pestle. Crushed samples were then 
dried and soaked in 'White Spirit' overnight. Excess solvent was decanted off and distilled water added (lh) until breakdown. Normal washing procedures and picking followed (as above).

The specimens selected to be photographically recorded were mounted on standard copper stubs with double-sided tape, shadowcasted with approximately $13 \mathrm{~A}^{\circ}$ coating of gold, and observed on a JEOL (JSM - T20) Scanning Electron Microscope, operated at $20 \mathrm{Kv}$. Elemental analysis of test composition were carried out under a JEOL (JSM -35C) Scanning Electron Microscope with a Link System X-Ray Spectrometer (860B Series), operated at $25 \mathrm{Kv}$. All figured specimens will be deposited and registered in the micropalaeontological collections of the PETROBRAS' Research Centre (CENPES).

\section{GEOLOGICAL SETTING}

The basin is the southern part of the Sergipe-Alagoas sedimentary complex, a structurally-elongated marginal basin located in northeastern Brazil (Fig. 1). It is closely related to the rifting and drifting phases of the South American and African continents in the Late Mesozoic (e.g., Asmus \& Baisch, 1983). The understanding of the biostratigraphical and palaeobiogeographical characteristics of its Cretaceous stratigraphic sequence is, therefore, of foremost significance for studies relating to the early geological history and subsequent palaeoceanographic evolution of the northern South Atlantic Ocean.

The marine sedimentary cycle in Sergipe (see Fig. 2) started with the deposition of extensive calci-siciliclastic and carbonate deposits (calcareous mudstones, oolitic/oncoliticbioclastic packstones/grainstones, conglomerates, sandstones, marls and shales) of the Riachuelo Formation, from late Aptian to late Albian times (cf. Ojeda \& Fugita, 1976; Feijó, 1980; Koutsoukos et al., in press). The subsequent Cenomanian-Coniacian phase comprises thick sequences of calcareous mudstones (Sapucari Member), in the onshore area, and marls and shales (Aracaju Member) scattered throughout the basin, of the Continguiba Formation (cf. Bengtson, 1983). The Cenomanian-Turonian succession has a typical transgressive pattern in seismic sections along the Brazilian continental margin (Beurlen, 1982) and is marked by an abrupt unconformity at its base. The geohistory and lithostratigraphy of the basin have been summarised in more detail previously (e.g., Schaller, 1969; Ojeda \& Fugita, op. cit.; Feijó, op. cit.; Bengtson, op.cit.; Koutsoukos et al., op. cit.; and references therein).

\section{Albian-Turonian Palaeoceanography}

During mid-Cretaceous times the basin experienced the effects of periodic expansion and intensification of a midwater oxygen-minimum zone, apparently ubiquitous in the northern South Atlantic at that time (e.g., Dias-Brito, 1982; Koutsoukos, 1984; Dias-Brito \& Azevedo, 1986; Viviers, 1986; Azevedo et al., 1987; Beurlen \& Regali, 1987; Herbin et al., 1987; Arai, 1988; Jacquin \& Graciansky, 1988; Magniez-
Jannin \& Jacquin, 1988; Spadini et al., 1988; and Mello et al., 1989). The mid-Cretaceous palaeoclimate was warm and equable and the temperature gradient between polar and equatorial regions was significantly lower than today (Luyendyk et al., 1972; Savin, 1977; Barron and Washington, 1982; Brass et al., 1982; Barron 1983). The relatively equable, warm palaeoclimate coupled with enhanced rates of evaporation at low latitudes and restricted physiography in the deep basins largely contributed to restrain bottom circulation, which led to the periodic development of stable salinity stratified water-masses and induced bottom oxygen depletion (Mello, 1988; Mello et al., op. cit.; Koutsoukos et al., in prep.). Higher rates of nutrient supply, probably resulting from increased continental runoff, led to widespread eutrophic conditions and to major changes in surface-water productivity.

Three maxima in oxygen depletion (dysaerobic/anaerobic conditions) are noticed in the succession, from middle shelf to upper slope environments: 1) in the late Aptian-earliest Albian (see Fig. 3); 2) in the early Cenomanian; and 3) in the latest Cenomanian-earliest Turonian (Koutsoukos et al., in prep.). Waning low-oxygen pelagic conditions (dysaerobic to aerobic) are apparent in the upper Albian succession of Sergipe (Koutsoukos et al., in press; Fig. 3), a probable consequence of less restricted oceanic exchange between the South and North Atlantic, with the establishment of more open oceanic circulation patterns. During early to middle Cenomanian times, lowering sea-level and more humid climate (increased continental runoff) coupled with at least two NW-SE transpressional pulses along the equatorial margin (R.P. de Azevedo, 1988, and personal communication, May 1989), could have further restricted the oceanic circulation patterns and contributed to the build-up of an oxygen-minimum zone of oceanic proportions.

A latest Cenomanian sea level rise is noticeable in Sergipe by the occurrence of upper slope thin laminated pelitic sediments, represented by the only known exposure of the Aracaju Member (locality Pati 2 ), in a carbonate-dominated sedimentary cycle (Mello et al., op.cit.). There is evidence of an expansion of the oxygen minimum zone over the continental shelf during the latest Cenomanian-earliest Turonian times, sporadically affecting the upper epipelagic layers, and very probably associated with this sea level maximum (Mello et $a l$., op.cit. ). This sea level rise in the latest Cenomanian is of world-wide significance (see Haq et al., 1987), as well as the rise and expansion of the oxygen minimum zone (Arthur et.al., 1987; Schlanger et al., 1987), the so-called "Oceanic Anoxic Event 2" (OAE) of Schlanger \& Jenkyns (1976), Arthur \& Schlanger (1979) and Jarvis et al . (1988).

\section{PREVIOUS STUDIES}

Recent investigations during the past two decades of midand Late Cretaceous radiolarian species have been given from the southeastern Brazilian margin (Campos Basin: Kotzian \& Eilert, 1987), western interior region of North America (Bergstresser, 1983), western Canada (Wall, 1975), California (Foreman, 1968; Pessagno, 1971, 1972 a, b, 1973, 1976, 


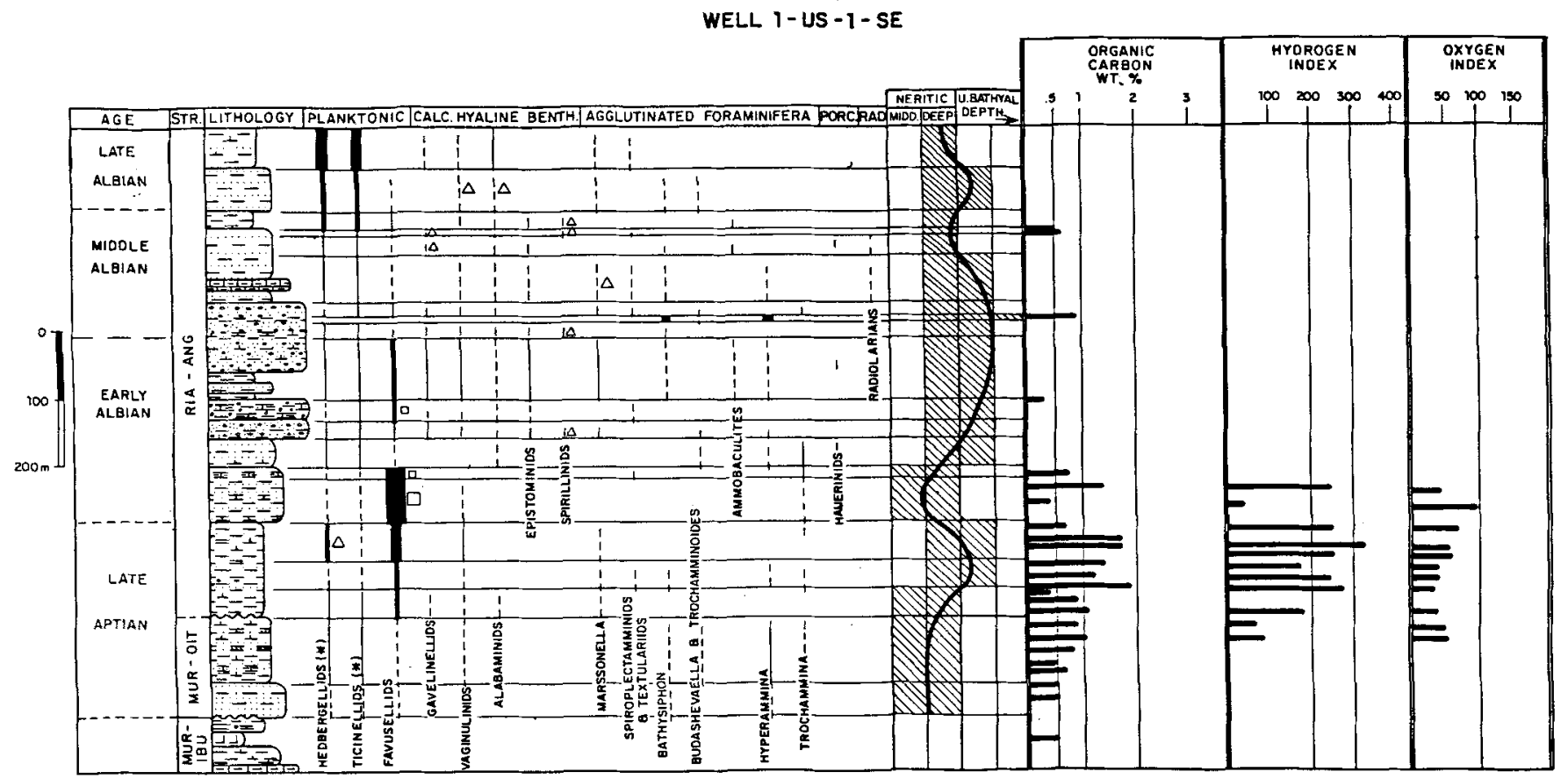

Fig. 3: Stratigraphic distribution, relative abundance and depositional palaeoenvironments of foraminifera and associated microfossils in the Albian section of well 1-US-1-SE, with geochemical logs (taken from Fig. 16 of Koutsoukos et al., in press).

Key: $\Delta<200 \mu \mathrm{m} ; \square 300-500 \mu \mathrm{m}$; * rugose and non-rugose specimens.

1977) NW African coastal basins (Agadir and Tarfaya basins, Morocco: Thurow et al., 1982; Wolfart, 1982; Kuhnt et al., 1986; Thurow \& Kuhnt, 1986), northern Italy (Euganean Hills: Kuhnt et al., op.cit. ), Romania (Dumitrica, 1970), western Siberia, U.S.S.R. (Koslova \& Gorbovetz, 1966), northern Australia (Surat Basin, Queensland: Haig \& Barnbaum, 1978), from DSDP Sites in the Atlantic (Foreman, 1977, 1978a, b; Wolfart, 1982), Pacific (Foreman, 1971, 1973 b, 1975) and Indian Oceans (Foreman, 1973a; Moore, 1973; Riedel \& Sanfilippo, 1974; Renz, 1974), and from Campanian tropical and subtropical oceans (Empson-Morin, 1984). The systematic study of Cretaceous diatoms has long been neglected and, elsewhere, very few accounts have appeared in the literature. The more recent reports are from the western interior region of North America (Bergstresser \& Krebs, 1983), western Canada (Given \& Wall, 1972; Wall, 1975), and northern Australia (Haig \& Barnbaum, 1978).

As can be seen, few studies have been published on the taxonomy and distribution of Cretaceous radiolarian taxa, and, even fewer on Cretaceous diatomaceous floras. This situation is made worse by the incomplete understanding of their biostratigraphical value and very rare preservation in the stratigraphical record, which usually places this less conspicuous microfossil group in a secondary level during conventional micropalaeontological studies. However, it is exactly this "rare" and "limited" occurrence in the stratigraphical record that makes the group a primary tool for palaeoecological and palaeoceanographical studies. The onset of radiolarians in middle Albian times and the drastic changes (in abundance and morphotypic composition) of the radiolarian and diatom populations in the uppermost Cenomanianlowermost Turonian of Sergipe are both related to the major palaeoceanographic events which affected most of the northern South Atlantic.

\section{DISTRIBUTION OF MICROFOSSILS \\ Radiolarians}

Low-diversity radiolarian assemblages are first recorded in Sergipe from rare occurrences in middle Albian outer shelfupper slope sediments of the Taquari Member of the Riachuelo Formation (well 1-US-1-SE, core \#4: $552.50 \mathrm{~m}$ and section 561-576m: Arachnosphaera (?) sp., Orbiculiforma sp. - see Fig. 3). An upper Albian outer shelf-upper slope section (well 1CRL-1-SE, core \#2-\#3: 1200.80-1214.50m) yield an abundant assemblage of pyritized nasselarians (Dictyomitra ex gr. multicostata Zittel, Lithostrobus sp. A., Lithostrobus sp. B, Gongylothorax sp. A; PI. 1, Figs. 1-2, 4-5, 9-12). From further upper Albian middle shelf to upper slope sections (well ]-CA-1-SE, core \#2: $761.80 \mathrm{~m}$, section $795-915 \mathrm{~m}$ ) rare low diversity nasselarians (Gongylothorax sp. A) and spumellarians [Arachnosphaera (?) sp. A] are also recovered.

Radiolarians are subsequently recorded throughout most of the Cenomanian-Turonian sections (see fig. 4). Nassellarian forms have been recovered only from uppermost Cenomanian to middle Turonian sections (Pl. 1, Figs 3,6-8) and seem to have thrived in relatively deep-water environments, in middle to upper bathyal pelagic biotopes. Spumellarian forms (Pl. 2, Figs. 1-11; Pl. 3, Figs. 1-14) are dominant in all the sections. In deeper water environments, however, members of the Spumellariina comprise about $70 \%$ of the species and $90 \%$ of 
the total number of radiolarians (e.g., deep neritic-upper bathyal biotopes of the uppermost Cenomanian-lowermost Turonian; Figs. 4 and 5). In lower Cenomanian (localities Itaporanga 2-3, Itaperoá 3; well 1-US-1-SE: 366-396m) and uppermost Turonian deposits (locality Mata 1) the assemblages are exclusively composed of spumellarian forms (Pl. 2, Figs. 1, 7-11; Pl. 3, Figs. 2-3, 7, 10-14). Furthermore, the changes in test size with depth of the spumellarian assemblages showed a "bimodal" pattern of distribution. The larger specimens of Arachnosphaera (?) sp. A (c. 300um in maximum diameter), the most common Spummellariina, are usually recorded in deepneritic to upper bathyal environments, whereas the larger morphotypes of Phaseliforma (c. $230 \mu \mathrm{m}$ in maximum length) and Orbiculiforma c. $360 \mu \mathrm{m}$ in maximum diameter) usually being found in shallower neritic environments.

The radiolarian faunas are more abundantly preserved in uppermost Cenomanian outer shelf-upper slope deposits (locality Pati 2), in lowermost Turonian middle-outer shelf sediments (locality Aroeirinha 4; well 1-US-1-SE: core \#1:101.10m, section 276-351m) and in lower-upper Turonian middle shelf strata (locality São Pedro 5). Higher diversity and increasing radiolaria/foraminifera ratios are also noticeable in these sediments.

The studied radiolarian assemblages are preserved as either unaltered siliceous tests (PI. 1, Fig. 6), pyritized (upper Albian radiolarians of well 1CRL-1-SE) or calcified tests (occurring most frequently), where the original amorphous silica forming the skeleton has been replaced; preservational processes which commonly occur in carbonate deposits (de Wever, 1983). The pyrite orcalcite replacement processes apparently have not affected the preservation of fine details of the test surface, as seen in several nasselarian specimens (see Pl. 1, Figs 1-2, 4-5, 9-12 - pyritized specimens; Pl. 1, Figs. 3, 7-8 calcified specimens).

The low diversity radiolarians from Sergipe (such as the assemblages of Dictyomitra ex gr. multicostata, Gongylothorax sp. A, Arachnosphaera (?) sp. A, Crucella messinae Pessagno, Histriastrum anisum Foreman, Orbiculiforma ex gr. monticelloensis Pessagno, Phaseliforma ex. gr. laxa Pessagno and Pseudoaulophacus parqueraensis Pessagno; see Fig. 3 and taxonomic notes) reveal taxonomic and morphotypic affinities with coeval assemblages reported from the southeastern Brazilian margin (Campos Basin: Kotzian \& Eilert, 1987), Caribbean area (Puerto Rico: Pessagno, 1963), western interior region of the United States (Colorado, Kansas, Wyoming: Bergstresser, 1983), eastern Atlantic regions (NW Africa, Morocco: Kuhnt et al., 1986), northern Australia (Queensland: Haig \& Barnbaum, 1978), western Canada sedimentary basin (Alberta: Wall, 1975), and northeastern Pacific margin (California Coast Ranges: e.g., Pessagno, 1971, 1972 a, b; Foreman, 1975). The evidence appears to suggest wide palaeobiogeographic distribution patterns of these radiolarian taxa at low and high latitudes during the midCretaceous.

\section{Diatoms}

Diatom frustules are only recorded from uppermost Cenomanian (locality Pati 2) and lowermost Turonian (locality Pati 1; well 1-US-1-SE: 336-351m) deposits (Figs 4 and 5). Six morphotypes are present in the assemblages (illustrated in Pl. 4, Figs 1-14). An outcrop of the earliest Turonian age (locality Pati 1), thought to have been deposited in a probable middle-outer shelf environment, yield an abundant diatom assemblage of discoid forms (morphotypes A, B and C), all represented by calcareous frustules, a result of preservational processes similar to the ones that affected the radiolarian assemblages. The record of diatom frustules in the uppermost Cenomanian-lowermost Turonian sections attests to the particular palaeoceanographic conditions at the time (see below).

\section{PALAEOECOLOGICAL IMPLICATIONS Preservation of Siliceous Tests}

In most recent sediments radiolarians and diatoms are absent through post-mortem dissolution of their tests. They are composed of relatively unstable amorphous silica (opaline biogenic silica) and are readily dissolved in normal sea water which is usually undersaturated with respect tonatural opaline silica (Berner, 1971). Furthermore, during laboratory experiments carried out by the first author, extant diatom frustules have been shown to have higher fragility and susceptability todissolution than radiolarian tests. Radiolarians are nowadays relatively common, however, only in certain areas of vigorous upwelling, such as the peri-equatorial Pacific and part of the northwestern African slope (e.g., Lisitzin, 1972; Diester-Haass, 1978).

In the outcrop sections of the Cotinguiba Formation chert nodules are commonly found, presumably formed from diagenetic dissolution and replacement of the unstable opaline tests of radiolarians and diatoms by calcedony, with subsequent formation of chert at certain horizons where the remobilised silica was concentrated. Depleted oxygen concentrations occurred sporadically in the bottom waters, as suggested by the usual occurrence of thin laminated dark grey marls and calcareous black shales with high organic carbon contents (Mello, 1988; Koutsoukos et al., in prep.). Enhanced primary productivity in the surface waters coupled with epi- and mesopelagic water masses saturated in silica (perhaps primarily contributed by deep-sea volcanism - cf. Berthou \& Bengtson, 1988 ), low $\mathrm{pH}$ and slightly negative redox-potential (Eh) of the bottom and interstitial waters, enriched in carbon dioxide, would have greatly favoured the biomineralization and postmortem preservation of these fragile siliceous organisms in the sediments.

\section{Palaeoceanography}

The development and distribution patterns of siliceous assemblages in the mid-Cretaceous succession of Sergipe is closely related to major palaeoceanographic changes that occurred in the northern South Atlantic at that time. An idealised palaeoceanographic model integrating radiolarian 


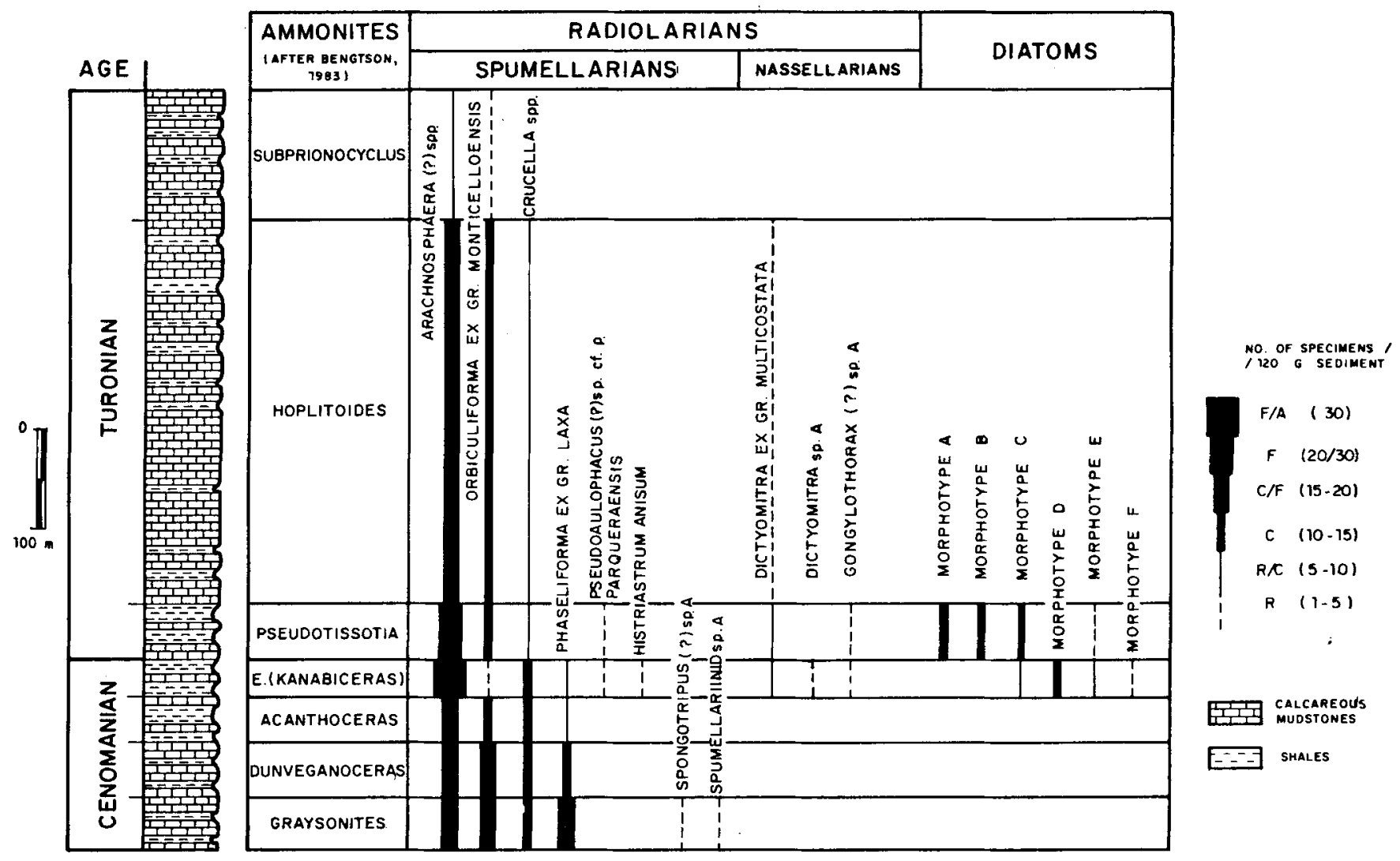

Fig. 4: Biochronostratigraphic distribution and relative abundance of radiolarians and diatoms in the Cenomanian-Turonian succession of the Sergipe Basin, onshore area. Composite data from outcrops and well-sections (see Appendix -1). Vertical scale is approximate.

and diatom assemblages is proposed for the CenomanianTuronian (see Fig. 5).

Spumellarian radiolarians are dominant throughout all the sequence. Nassellarian forms are recorded from upper Albian and uppermost Cenomanian to middle Turonian deposits and seem to have thrived in relatively deep-water environments. These radiolarian assemblages apparently suggest open-water conditions with a peak in abundance and diversity in middleouter shelf or greater depths (i.e., in excess of 30/50 meters Fig. 5). On the other hand, diatom frustules appear to have been more abundant in shallower neritic environments and have only been recorded from uppermost Cenomanian and lowermost Turonian deposits (Fig. 4 and 5).

The apparently restricted record of radiolarian-rich beds, generally limited to certain time-intervals and palaeogeographic settings, caused some workers to refer to them as 'The Radiolarian Event' (Jenkyns \& Winterer, 1982), that is to say, times in the geological record when siliceous biogenic accumulations was favoured and usually associated with regional palaeoceanographic events (Jenkyns \& Winterer, op.cit.; Baumgartner, 1984; Miskell et al., 1985). Similar features have been reported for sediments from many areas of the world, deposited during OAE's (Kuhnt et al., 1986; Schlanger et al., 1987) and during older upwelling events (e.g. Mazagan Escarpment, offshore Central Morocco: Leckie,
1981; Monterey Formation, California: Katz \& Elrod, 1983: Rayda Formation, Arabian Peninsula: Connally \& Scott, 1985). Upwelled nutrient-rich deep waters would promote high primary productivity in surface waters and favour a biogenic siliceous record (Jenkyns \& Winterer, op. cit.; Leckie, op. cit.). However, the episodes of siliceous radiolarian and diatom biomineralization/preservation in Sergipe are not merely interpreted as indications of coastal upwelling events, as the palaeoceanographic evidence suggests restricted physiography at the deep-oceanic basic for most of the midCretacious with salinity-stratified water masses (Mello $c t a l$., in press; Koutsoukos et al., in prep). High primary productivity in the epipelagic layers is most likely to have been a response to high nutrient levels (eutrophic conditions), perhaps largely controlled by increased continental runoff. Increasing sealevels and improved deep circulation (such as in the latest Cenomanian-earliest Turonian) may also have significantly contributed to overturn nutrient-rich oxygen-depleted bottom waters and, consequently, increase surface-water productivity (cf. Arthur \& Schlanger, 1979).

The earlier onset of the radiolarian assemblages in mid-late Albian times (with waning low-oxygen pelagic conditions), through scattered occurrences, is inferred to be a response to better developed oceanic circulation patterns and to a water mass with high levels of dissolved silica, perhaps originated 


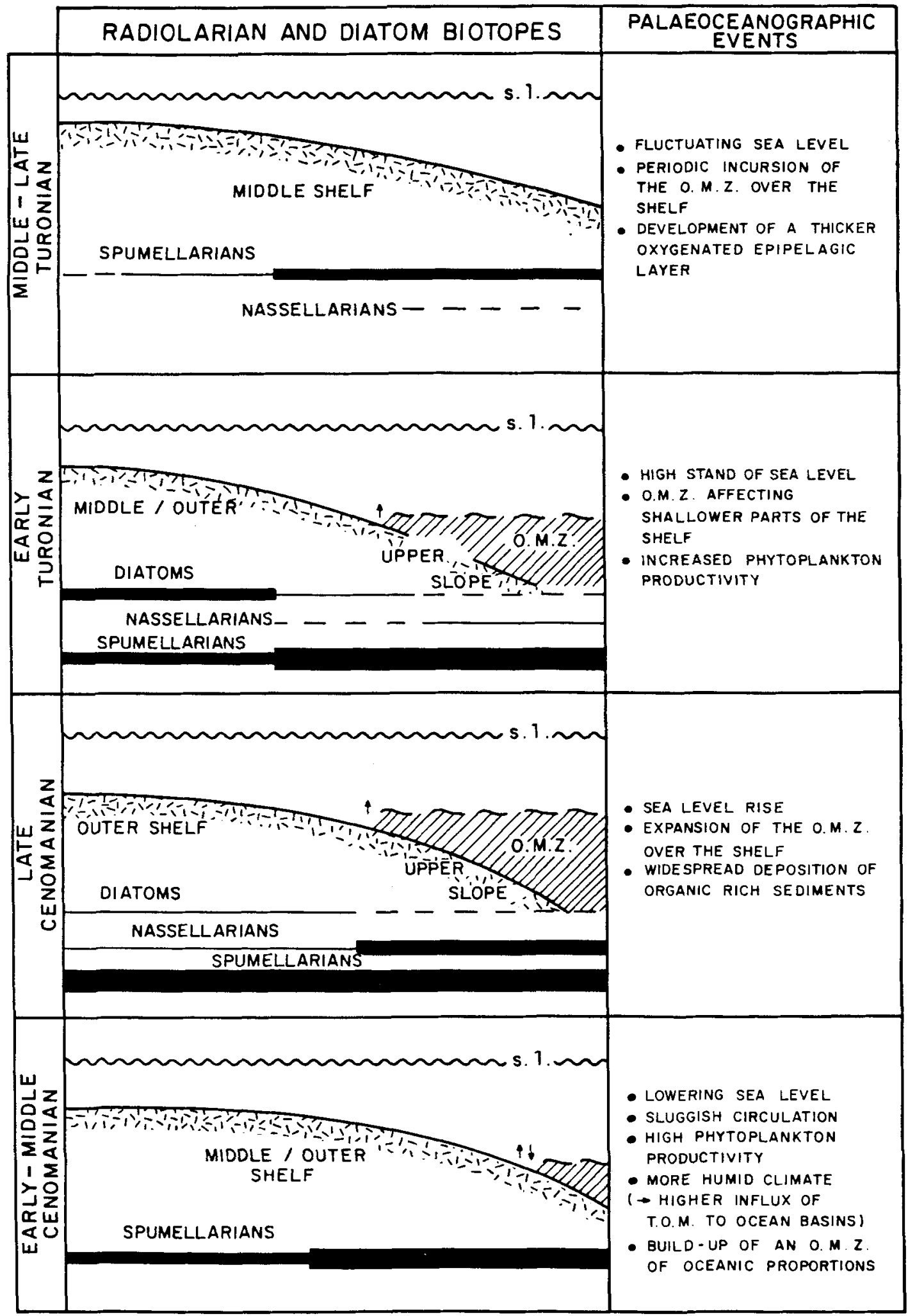

KEY: $\quad{ }^{R}-\frac{C}{F}$ A $\quad \begin{gathered}\text { O.M.Z. - OXYGEN MINIMUM ZONE } \\ \text { T.O.M. - TERIGENOUS ORGANIC MATTER }\end{gathered}$

Fig. 5: Idealised reconstruction of the Cenomanian-Turonian palaeoceanographic evolution (inferred after Mello et al., 1989; Koutsoukos \& Hart, in press; Koutsoukos ct al., in prep. ) and distribution of radiolarian and diatom biotopes in the Sergipe Basin, onshore area. 
by deep-sea volcanic processes in the formation of early oceanic crust and the mid-oceanic ridge. On the other hand, the record of radiolarians and diatoms throughout the Cenomanian-Turonian succession (Figs. 4 and 5) is commonly associated with dysaerobic to quasi-anaerobic bottom conditions. The higher abundance and diversity are observed in the upper Cenomanian-lower Turonian deposits (Fig. 4). These biotic patterns are recognised in coeval sediments of most marine basins (e.g. Jenkyns \& Winterer, 1982; Thurow et al., 1982; Kuhnt et al., 1986; Arthur et al., 1987) and have been associated with high-sea level, increased productivity and the onset of intensified bottom oxygen depletion over the shelf during latest Cenomanian-earliest Turonian times.

\section{CONCLUDING REMARKS}

Radiolarian faunas are first recorded in the middle-late Albian (Riachuelo Formation), from scattered occurrences, and subsequently throughout most of the CenomanianTuronian succession (Continguiba Formation). Spumellarian forms [mostly represented by Arachnosphaera (?), Crucella, Orbiculiforma and Phaseliforma species] are dominant in all the sections. Nassellarian forms seem to have thrived in relatively deep-water environments, in middle neritic to upper bathyal pelagic biotopes, and have been recorded from upper Albian and uppermost Cenomanian to lower-upper Turonian sediments. Dictyomitra ex gr. multicostata, Gongylothorax sp. A and Lithostrobus spp. are the most common morphotypes of Nassellariina recovered during this study. Diatom frustules are only recorded from uppermost Cenomanian and lowermost Turonian deposits. These seem to have been more abundant in shallower neritic environments.

The development of siliceous assemblages in the midCretaceous succession of Sergipe is closely related with major palaeoceanographic changes that occurred in the northern South Atlantic at that time. The onset of the radiolarian assemblages in middle-late Albian times is thought to be a response to better developed oceanic circulation patterns and to a water mass with high levels of dissolved silica, perhaps generated by deep-sea volcanic processes in the formation of early oceanic crust and the mid-oceanic ridge. On the other hand, the record of radiolarians and diatoms throughout the Cenomanian-Turonian succession is not only in keeping with high epipelagic primary productivity in well-oxygenated surface waters, saturated in dissolved silica, but also suggests that the bottom and interstitial waters were enriched in carbon dioxide, had a low $\mathrm{pH}$ and a slightly negative redox-potential (Eh). The overall conditions would have favoured the biomineralization and post-mortem preservation of siliceous organisms increasing, therefore, the radiolaria+diatom/ foraminifera ratio in the sediments, which supports the conclusions of several previous authors.

The low-diversity radiolarians from Sergipe reveal taxonomic and morphotypic affinities with coeval assemblages reported from the southeastern Brazilian margin (Campos Basin), Caribbean area (Puerto Rico), western interior region of North America (Colorado, Kansas, Wyoming), eastern
Atlantic regions (NW Africa), northern Australia (Queensland), western Canada sedimentary basin (Alberta), and northeastern Pacific margin (California Coast Ranges). The evidence appears to suggest wide palaeobiogeographic distribution patterns of these radiolarian taxa at low and high latitudes during the mid-Cretaceous.

\section{TAXONOMIC NOTES}

Phylum Protozoa

Subphylum Sarcodina

Class Actinopodea

Subclass Radiolaria

Entries and taxonomic remarks for each radiolarian species are brief. References are restricted to the original description of the species and to relevant references used in this study. Furthermore, because of the fragmentation of tests and common recrystallisation, no decision could be made on specific attribution of several morphotypes. Such forms were either placed in single species-groups, each regarded with broad morphological variability, or placed in open nomencláture.

Order Polycystida

Suborder Nassellariina

Gongylothorax sp. A.

(Pl. 1, figs. 1-3)

Remarks. This species is characterised by its small (c. 190$300 \mu \mathrm{m}$ in maximum diameter), subspherical shape, covered by sharply defined pentagonal or hexagonal depressions.

Range. late Albian to earliest Turonian.

Occurrence. wells 1-CA-ISE, 1-CRL-1-SE, 1-US-1-SE.

\section{Dictyomitra ex gr. multicostata Zittel}

$$
\text { (Pl. 1, figs 4-7) }
$$

1876 Dictyomitra multicostata Zittel: 81 , pl. 2, fig. 2

1976 Dictyonitra multicostata Zittel; Pessagno: 52, pl. 14, figs. 4-9

1983 Dictyomitra multicostata Zittel; Bergstresser: 880, figs. 6 a-d

Remarks. Dictyomitra ex gr. multicostata morphotypes are characterised by having a small (c. $200-210 \mu \mathrm{m}$ in maximum length) elongate, subconical test consisting of 8 to 10 segments, gradually increasing in diameter; in some cases the last 3 to 4 segments have the same diameter, or the last two have progressively smaller widths; each segment has one transverse row of very small pores near the segment suture; the surface contains numerous longitudinal costae.

Range. Late Albian to early-Late Turonian.

Occurrence. Localities Aroẹirinha 4, Pati 2, São Pedro 5, wells 1-CRL-1-SE, 1-US-1-SE.

$$
\begin{aligned}
& \text { Dictyomitra(?) sp. A } \\
& \text { (Pl. 1, fig. 8) }
\end{aligned}
$$

Remarks. Test moderately large (c. $400 \mu \mathrm{m}$ in maximum length), elongate, subconical, consisting of approximately 
nine segments, with the last two segments having slightly smaller diameter than the previous segment; test surface probably with small pores (not well distinguished due to bad preservation). The lack of vertical costae, if at all present, may be due to recrystallisation. The morphotypes somewhat resemble specimens of Dictyomitra rotundata (Aliev) illustrated by Foreman (1978-a, p. 841, pl. 1, figs. 1-3) from the late Albian-Cenomanian of Angola Basin. However, because of uncertainty as to the exact diagnosis of the present species it is tentatively assigned to the Dictyomitra genus.

Range. Latest Cenomanian.

Occurrence. Locality Pati 2 (rare occurrence)

\section{Lithostrobus sp. A}

(Pl. 1, figs. 9-11)

Remarks. Specimens of Lithostrobus sp. A have a small (about $290 \mu \mathrm{m}$ in maximum length), elongate, subconical test with 6 segments, gradually increasing in diameter, with the last segment having slightly smaller diameter than the previous one; last 4 segments inflated, with well-defined segmental strictures; reticulate test surface covered with numerous small polygonal depressions.

Range. Late Albian

Occurrence. Well 1-CRL-1-SE.

\section{Lithostrobus sp. B}

$$
\text { (Pl. 1, fig. 12) }
$$

Remarks. Lithostrobus sp. B morphotypes are distinguished by having a minute (c. $160 \mu \mathrm{m}$ in maximum length), elongate, subconical test with 6 segments, gradually increasing in diameter; test surface covered with numerous small pores.

Range. Late Albian.

Occurrence. Well 1-CRL-1-SE.

Suborder Spumellariina

Arachnosphaera (?) sp. A

$$
\text { (Pl. 2, figs. 1-3) }
$$

Remarks. This is by far the most abundant species-group amongst the spumellarians. They are characterised by spherical shaped specimens of variable sizes (c. 110-360 $\mu 19$ in maximum diameter), with a spongy wall texture and very thin pores.

Range. Late Albian to Turonian

Occurrence. Localities Aroeirinha 4, Itaporanga 2-3, Itaperoá 3, Mata 1, Pati 2, Pedra Branca 17, São Pedro 5, wells 1-CA1-SE, 1-US-1-SE.

\section{Crucella irwini Pessagno}

(Pl. 2, figs. 4-6)

1971 Crucella irwini Pessagno: 55, pl. 9, figs. 4-6.

Remarks. Specimens of $C$. irwini are characterised by having large (c. $400-450 \mu \mathrm{m}$ in maximum diameter) tests with four long and slender rays, tapering distally and nearly equal in length; central area with shallow lacuna.

Range. Latest Cenomanian to early-Late Turonian.

Occurrence. Localities Pati 2, São Pedro 5.

\section{Crucella messinae Pessagno}

(Pl. 2, figs. 7-8)

1971 Crucella messinae Pessagno: 56, pl. 6, figs. 1-3.

Remarks. The species is distinguished by its moderately large (c. 330-380 $\mu \mathrm{m}$ in maximum diameter) cruciform test with cylindrical longitudinal rays and by lacking a lacuna in its central area.

Range. Early Cenomanian.

Occurrence. Locality Itaperoá 3.

\section{Crucella (?) sp. A}

(PI. 2, figs. 9-11)

Remarks. This species is characterised by having a large (c. $400-550 \mu \mathrm{m}$ in maximum diameter) test with shorter rays, subcylindrical longitudinally; rays and central area planiform horizontally.

Range. Early Cenomanian to middle Turonian.

Occurrence. Localities Itaperoá 3, São Pedro 5, well 1-US1-SE.

\section{Histiastrum anisum Foreman}

(Pl. 3, fig. 1)

\section{Explanation of Plate 1}

All illustrations are scanning electron photomicrographs.

Scale bars $=100 \mu \mathrm{m}$.

\section{Radiolarians (Nasselariina)}

Figs. 1-3 Gongylothorax sp. A Fig. 1, 2, well 1-CRL-1-SI: \#2: 1203.20m (upper Albian); Fig. 3, well 1-US-1-SE, \#1: 101.10m (lowermost Turonian).

Figs. 4-7. Dictyomitra ex gr. multicostata Zittel.

Figs. 4,5, well 1-CRL-1-SE, \#2: 1203.20m (upper Albian); 1·ig. 6, locality Aroeirinha 4 (lowermost Turonian); Fig. 7, well 1-US-1SE: $366-381 \mathrm{~m}$ (lowermost Turonian).

Fig. 8. Dictyomitra (?) sp. A, locality Pati 2 (uppermosi Cenomanian).

Figs. 9-11. Lithostrobus sp.A, specimens from well 1-CRL-1-Sl;; \#2: 1203.20m (upper Albian).

Fig. 12. Lithostrobus sp. B, specimens from well I-CRL,-I-SI:, \#2:1203.20m (upper Albian). 


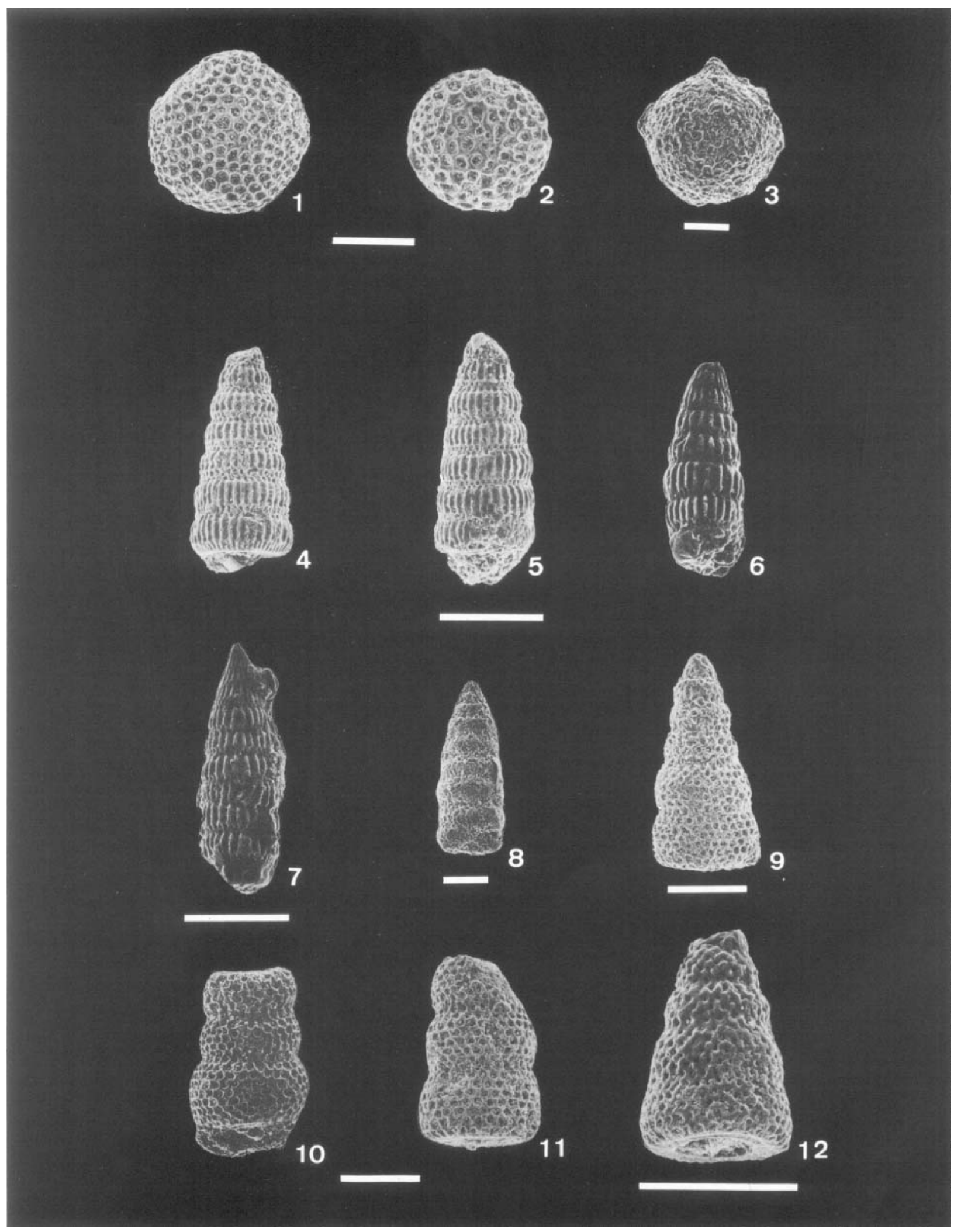


1978 Histiastrum anisum Foreman: 841, pl. 1, figs. 5-7

Remarks. The species is distinguished by its large (c. $480 \mu \mathrm{m}$ in maximum length) test with the presence of three to four irregularly developed arms.

Range. Latest Cenomanian.

Occurrence. Locality Pati 1 (rare occurrence).

Orbiculiforma ex gr. monticelloensis Pessagno

$$
\text { (Pl. 3, figs. 2-5) }
$$

1973 Orbiculiforma monticelloensis Pessagno: 72, pl. 16, figs. $5-6$, pl. 18 , figs. $1-2$

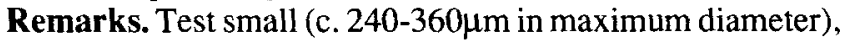
disc-shaped, nearly circular in outline, with a vertical to rounded periphery; central cavity relatively wide and shallow; centre slightly raised; fine meshwork.

Range. Early Cenomanian to early-Late Turonian.

Occurrence. Localities Aroeirinha 4, Itaperoá 3, São Pedro 5, well 1-US-1-SE.

\section{Phaseliforma ex gr. laxa Pessagno}

(Pl. 3, figs. 6-7)

1972 Phaseliforma laxa Pessagno: 276, pl. 23, figs. 7-9.

Remarks. Specimens of $P$. ex gr. laxa are characterised by having small (c. 140-230 $\mu \mathrm{m}$ in maximum length), elongate, subellipsoidal tests, varying in width (c. $70-130 \mu \mathrm{m}$ in maximum width); smooth surface with fine meshwork.

Range. Cenomanian.

Occurrence. Localities Itaperoá 3, Pati 2.

\section{Pseudoaulophacus parqueraensis Pessagno}

$$
\text { (Pl. 3, figs. 8-9) }
$$

1963 Pseudoaulophacus parqueraensis Pessagno: 204, pl. 2, figs 4,7 , pl. 6, figs. 4-5.

1972 Pseudoaulophacus parqueraensis Pessagno; Pessagno: 309 , pl. 30, fig. 4 .

Remarks. This species is distinguished by its moderately small (c. 300 $\mu$ m in maximum diameter), circular test, lenticular in peripheral view; lobate periphery with 9 lobes, each lobe bearing a short spine, which is commonly not preserved.

Range. Latest Cenomanian to earliest Turonian.

Occurrence. Localities Aroeirinha 4, Pati 2.

\section{Spongotripus (?) sp. A}

(Pl. 3, figs. 10-12)

Remarks. Moderately large (c. $300-400 \mu \mathrm{m}$ in maximum diameter), irregular shaped specimens, with apparently three to four rays and thickened central area.

Range. Early Cenomanian.

Occurrence. Locality Itaperoá 3.

$$
\begin{aligned}
& \text { Genus and species indet } \\
& \text { Spumellariinid sp. A. } \\
& \text { (Pl. 3, figs. 13-14) }
\end{aligned}
$$

Remarks. This species is distinguished by having a small (c. 200-320 $\mu \mathrm{m}$ in maximum diameter) test with three irregularly developed rays (which give the test a triangular shape) and thickened central area.

Range. Early Cenomanian.

Occurrence. Locality Itaperoá 3.

\section{Class Diatomacea}

Remarks. Specimens of morphotypes D, E and F, with an angular or rounded periphery, are tentatively thought to be diatom frustules, mostly based on their non-spongy, smooth and even outer surface and general similarity to the group.

Morphotype A

(Pl. 4, figs. 1-2)

Remarks. Small (c. 200-230 $\mu$ m in maximum diameter), broad, thin, flattened discs (biscuit shape).

Range. Earliest Turonian.

Occurrence. Locality Pati 1.

\section{Morphotype B}

(Pl. 4, figs. 3-4)

Remarks. Small (c. $190 \mu \mathrm{m}$ in maximum diameter), broad, moderately thick, flattened discs, with a vertical periphery (pill-shaped).

Range. Earliest Turonian.

Occurrence. Locality Pati 1.

\section{Explanation of Plate 2}

All illustrations are scanning electron photomicrographs.

Scale bars $=100 \mu \mathrm{m}$.

\section{Radiolarians (Spumellariina)}

Figs. 1-3. Arachnosphaera (?) Fig. 1, locality Mata 1-5 (uppermost Turonian); Figs. 2, 3, locality Pedra Branca 17 (lower to middle Turonian).

Figs. 4-6. Crucella irwini Pessagno, locality Pati 2 (uppermost Cenomanian).

Figs. 7-8. Crucella messinae Pessagno, locality Itaperoá (lower Cenomanian).

Figs. 9-11. Crucella (?) sp. A Fig. 9, locality Itaperoá 3 (lower Cenomanian); Figs. 10, 11, well 1-US-1-SE. \#1: 101.10m (lowermost Turonian). 

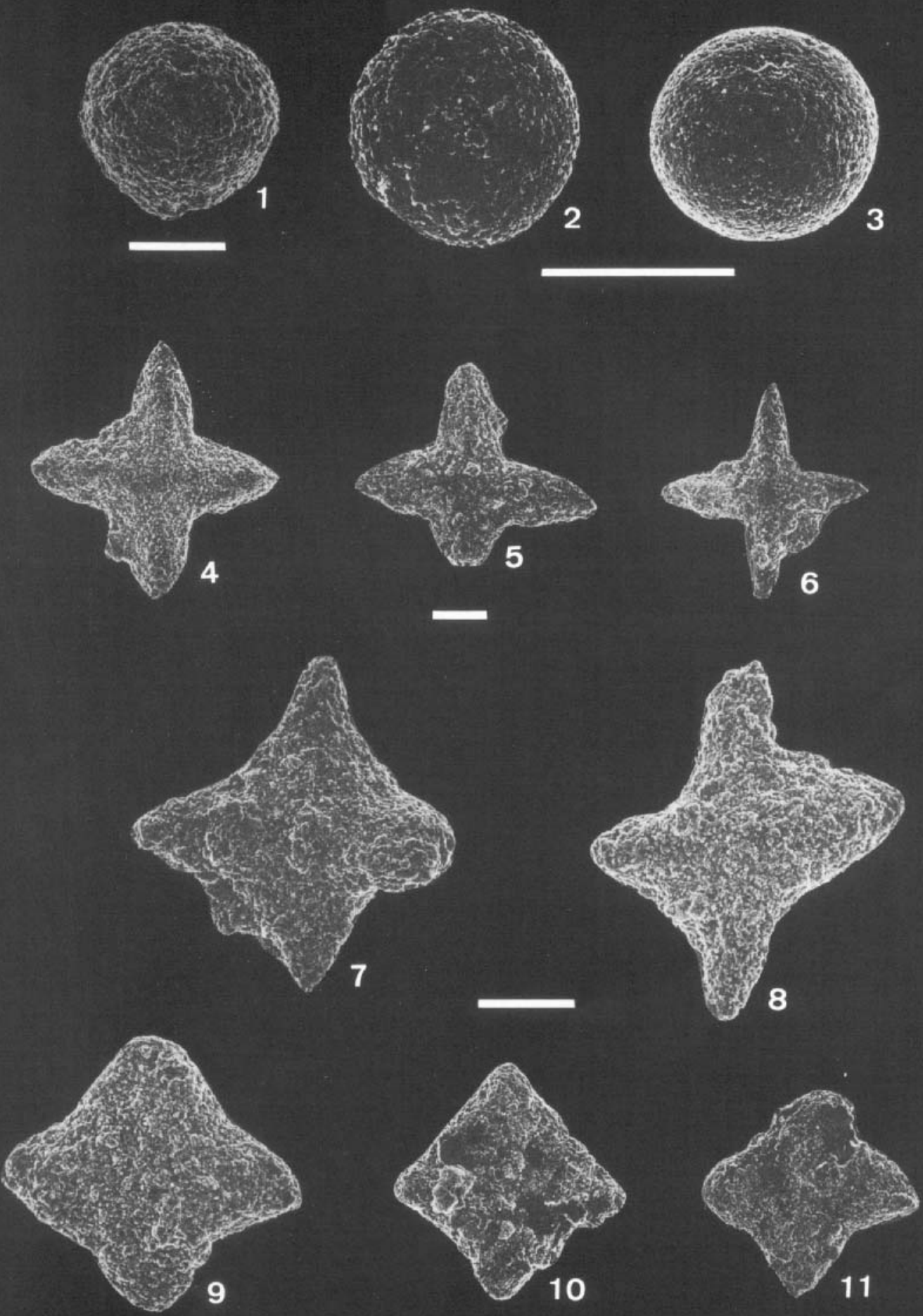
Morphotype C .

(Pl. 4, figs. 5-8)

Remarks. Minute (c. $120-190 \mu \mathrm{m}$ in maximum diameter), thick, flattened discs (drum-like forms).

Range. Latest Cenomanian to earliest Turonian.

Occurrence. Locality Pati 1, Pati 2, well 1-US-1-SE

Morphotype D

(Pl. 4, figs. 9-10)

Remarks. Moderately small (c. $280 \mu$ m in maximum diameter), lenticular, moderately thin, biconvex discs (lentil-shaped); surface smooth and even.

Range. Latest Cenomanian.

Occurrence. Locality Pati 2.

$$
\begin{gathered}
\text { Morphotype E } \\
\text { (Pl. 4, figs. 11-12) }
\end{gathered}
$$

Remarks. Moderately small (c. 300 $\mu$ m in maximum diameter), broad, moderately thick, flattened discs, with a rounded periphery (biscuit-shaped); surface smooth and even.

Range. Latest Cenomanian to earliest Turonian.

Occurrence. Localities Pati 1, Pati 2.

$$
\begin{gathered}
\text { Morphotype F } \\
\text { (P1. 4, figs. 13-14) }
\end{gathered}
$$

Remarks. Small (c. $240 \mu \mathrm{m}$ in maximum diameter), short, thick, flattened disc, with a rounded periphery (pill-shaped); surface smooth and even.

Range. Latest Cenomanian.

Occurrence. Locality Pati 1.

\section{ACKNOWLEDGEMENTS}

We would like to express our thanks to Petróleo Brasileiro S.A. (PETROBRAS), Riode Janeiro, for permission to publish this paper; to the draft section of PETROBRAS/CENPES for providing the final versions of the figures; and to Mr. G. Beurlen (PETROBRAS/CENPES) and an anonymous referee for the critical reading of the manuscript and several constructive suggestions.

\section{Manuscript received November 1988 \\ Revised Manuscript accepted December 1989.}

\section{REFERENCES}

Arai, M. 1988 Geochemical reconnaissance of the midCretaceous anoxic event in the Santos Basin, Brazil. Rev. Bras. Geoc., 18, (3), 273-282.

Arthur, M. A. \& Schlanger, S. O. 1979. Cretaceous 'oceanic anoxic events' as casual factors in development of reefreservoired giant oil fields. Am. Ass. Petr. Geol., Bull., Tulsa 63 870-885.

Arthur, M. A., Schlanger, S. O. \& Jenkyns, H. C. 1987. The Cenomanian-Turonian Oceanic Anoxic Event, II. Palaeoceanographic controls on organic-matter production and preservation. In Brooks, J. \& Fleet, A. J. (Eds. ), Marine Petroleum Source Rocks, Geol. Soc., Spec. Publication, 26, 401-420, Blackwell Scientific Publications.

Asmus, H, \& Baisch, P. R. 1983. Geological evolution of the Brazilian continental margin. Episodes, 4, 3-9.

Azevedo, R. L. M., Gomide, J. \& Viviers, M. C. 1987. Geohistória da Bacia de Campos, Brasil: do Albiano ao Maastrichtiano. Rev. Bras. Geoc., 17 (2), 139-146.

Azevedo, R. P. 1988. The Brazilian equatorial Atlantic continental margin: pull-apart and extensional basins along a major mid-Cretaceous transform fault zone. Tectonic Studies Group, 19th Ann. Meet. (15-18 Dec. 1988), Abstracts.

Barron, E. J. 1983. A warm equable Cretaceous: the nature of the problem. Earth-Sc. Reviews, Amsterdam, 19 (4), 305-338.

Barron, E. J. \& Washington, W. M. 1982. Cretaceous climate: a comparison of atmospheric simulations with the geologic record. Palaeog., Palaeoc., Palaeoec., Amsterdam, 40 (1-3), 103-133.

Baumgartner, P. O. 1984. A Middle Jurassic-Early Cretaceous low-latitude radiolarian zonation based on Unitary associations and age of Tethyan radiolarites.Eclogae geol. Helv., Basel, 77 (3), 729-837.

Bengtson, P. 1983. The Cenomanian-Coniacian of the Sergipe basin. Fossils and Strata, Oslo, 12, 1-78.

Bergstresser, T. J. 1983. Radiolaria from the Upper Cretaceous Pierre Shale, Colorado, Kansas, Wyoming,J.Paleont., Tulsa, 57 (5), 877-882.

Bergstresser, T. J. \& Krebs, W. N. 1983. Late Cretaceous (Campanian-Maastrichtian) diatoms from the Pierre Shale,

\section{Explanation of Plate 3}

All illustration are scanning electron photomicrographs

Scale bars $=100 \mu \mathrm{m}$.

\section{Radiolarians (Spumellariina)}

Fig. 1. Histriastrum anisum Foreman, locality Pati 2 (uppermost Cenomanian).

Figs. 2-5 Orbiculiforma ex. gr. monticelloensis Pessagno, locality Itaperoá 3 (lower Cenomanian); Figs. 4, 5, well 1-US-1-SE, \#1: $101.10 \mathrm{~m}$ (lowermost Turonian).

Figs. 6-7. Phaseliforma ex gr. laxa Pessagno Fig. 6, locality Pati 2 (uppermost Cenomanian); Fig. 7, locality Itaperoá 3 (lower Cenomanian)

Figs. 8-9. Pseudoaulophacus parqueraensis Pessagno, locality Pati 2 (uppermost Cenomanian).

Figs. 10-12. Spongotripus (?) sp.A, locality Itaperoá 3 (lower Cenomanian).

Figs. 13-14. Spumellariinid sp. A, locality Itaperoá (lower Cenomanian). 
Radiolarians and Diatoms from Cretaceous of Sergipe Basin, Brazil

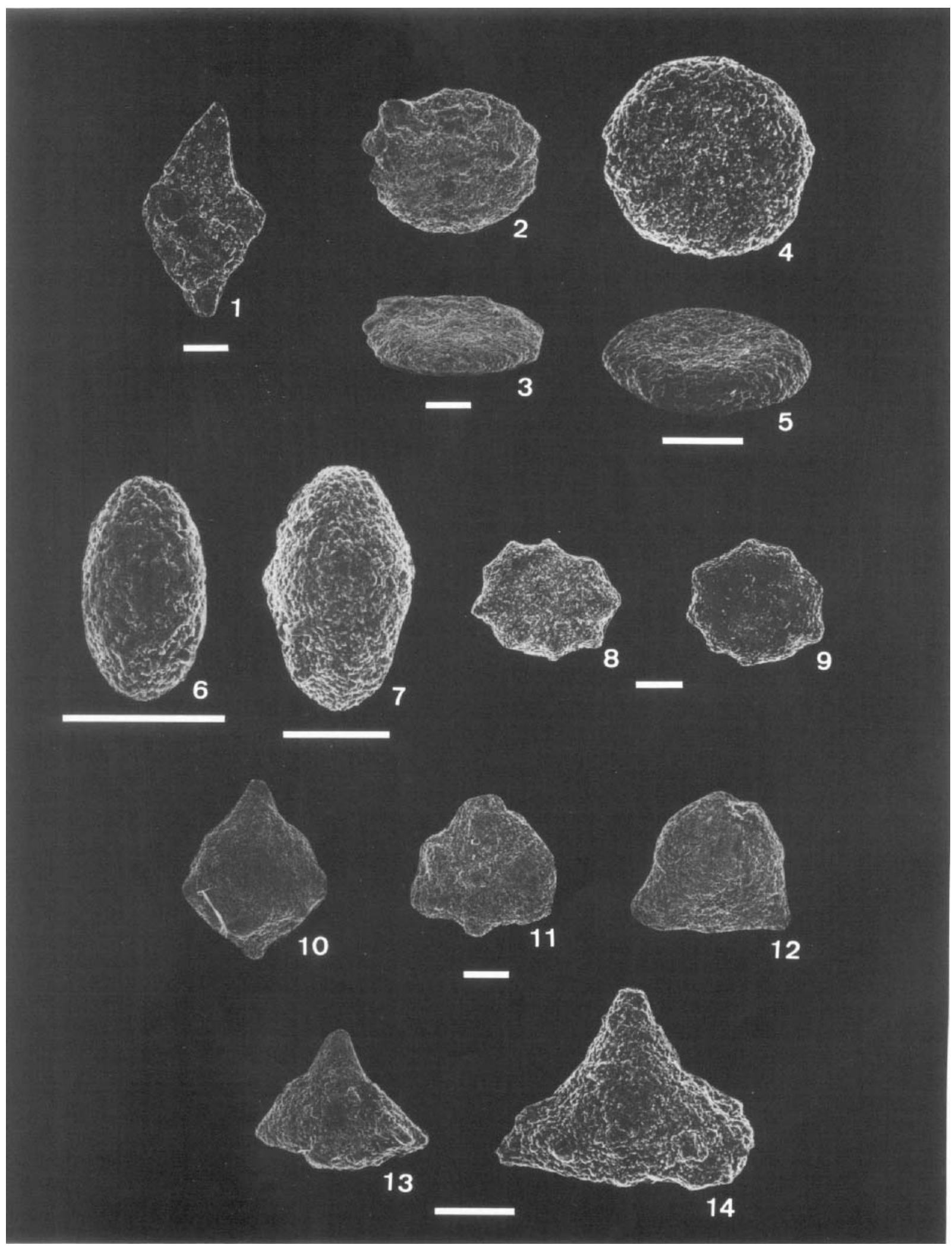


Wyoming, Colorado and Kansas. J. Paleont., Tulsa, 57 (5), 883-891.

Berner, R. A., 1971. Principles of chemical sedimentology. McGraw-Hill, New York.

Berthou, P.-Y. \& Bengtson, P., 1988. Stratigraphic correlation by microfacies of the Cenomanian-Coniacian of the Sergipe basin, Brazil. Fossils and Strata, Oslo, 21, 1-88.

Beurlen, G. 1982. Bioestratigrafia e geoistória de secão marinha da margem continental brasileira. Bol. Técn. PETROBRAS, Rio de Janeiro, 25 (2), 77-83.

Beurle, G., \& Regali, M. S. P. 1987. O Cretáceo da plataforma continental do Maranhão e Pará, Brasil: bioestratigrafia e evolucão paleoambiental. Bol. Geoc. PETROBRAS, 1 (2), 135-155.

Brass, G. W., Southam, J.R. \& Peterson, W.H. 1982. Warm saline bottom water in the ancient ocean. Nature, 296, 620623.

Connally, T. C. \& Scott, R. W. 1985. Carbonate sediment-fill of an oceanic shelf, Lower Cretaceous, Arabian Peninsula.In Deep-Water Carbonates - a Core Workshop , SEPM Core Workshop, New Orleans, 6, 266-302.

Dias-Brito, D. 1982. Evolucâo paleoecológica de Bacia de Campos durante a deposicão dos calcilutitos, margas e folhelhos da Formacão Macaé (Albiano e Cenomaniano?). Bol. Técn. PETROBRAS, 25 (2), 85-97.

Dias-Brito, D. \& Azevedo, R.L.M. 1986. As sequiências deposicionais marinhas da Bacia de Campos sob a ótica paleoecológica. XXXIV Congr. Bras. Geol., Anais, 1, 38-49.

Diester-Haas, L., 1978. Sediments as indicators of upwelling. In Boje, R. \& Tomczak, M., eds, Upwelling Ecosystems, Springer-Verlag, Berlin, 261-281.

Dumitrica, P. 1970. Crypotocephalic and cryptothoracic Nassellaria in some Mesozoic deposits of Romania. Rev. Roum. Geol. Geophys. Geogr., Ser. Geol., 14 (1), 45-124.

Empson-Morin, K. M. 1984. Depth and latitude distribution of Radiolaria in Campanian (Late Cretaceous) tropical and subtropical oceans. Micropaleont., New York, 30 (1), 87115.

Feijó, F. J. 1980. Estudo dos carbonatos Muribeca e Riachuelo no Alto de Aracaju - Bacia Sergipe/Alagoas - nordeste do Brasil. XXXI Congr. Bras. Geol., Anais, 1, 320-332.

Foreman, H. P. 1968. Upper Maestrichtian Radiolaria of California. Paleont. Assoc., Spec. Paper, 3, 1-82.
Foreman, H.P. 1971. Cretaceous Radiolaria, Leg 7, DSDP. Init. Rep. Deep Sea Drill. Proj., Washington, 7 (2), 1673-1693.

Foreman, H. P. 1973 a. Radiolaria of Leg 10 with systematics and ranges for the families Amphipyndacidae, Astostrobiidae, and Theoperidae.Init.Rep.Deep Sea Drill.Proj., Washington, 10, 407-474.

Foreman, H. P. 1973 b. Radiolaria from DSDP Leg 20. Init.Rep. Deep Sea Drill. Proj., Washington, 20, 249-305.

Foreman, H. P. 1975. Radiolaria from the North Pacific DSDP Leg 32. Init.Rep. Deep Sea Drill. Proj., Washington, 32, 579 . 676.

Foreman, H. P. 1977. Mesozoic Radiolaria from the Atlantic Basin and its borderlands. Stratigr. Micropalaeont. Atlantic Basin and Borderlands, Elsevier, Amsterdam, pp. 305-320.

Foreman, H. P. 1978a. Mesozoic Radiolaria in the eastern South Atlantic, Deep Sea Drilling Project, Leg 40. Init. Rep. Deep Sea Drill. Proj., Washington, 40, 839-843.

Foreman, H. P. 1978b. Mesozoic Radiolaria in the Atlantic Ocean off the northwest coast of Africa DSDP Leg 41. Init. Rep. Deep Sea Drill. Proj., Washington, 41, 739-761.

Given, M. M. \& Wall, J. H. 1971. Microfauna from the Upper Cretaceous Bearpaw Formation of South-Central Alberta. Can. Petrol. Geol., Bull., 19 (2), 502-544.

Hajos, M. \& Stradner, H. 1975. Late Cretaceous Archaeomonadaceae, Diatomaceae, and Silicoflagellatae from the South Pacific Ocean, Deep Sea Drilling Project, Leg 29, Site 275. In. Rep. Deep Sea Drill, Proj., Washington, 29. 913-1009.

Haig, D. W. \& Barnbaum, D. 1978. Early Cretaceous microfossils from the type Wallumbilla Formation, Surat Basin, Queensland, Alcheringa, 2, 159-178.

Haq, B. U., Hardenbol, J. \& Vail, P.R. 1987. Chronology of fluctuating sea levels since the Triassic. Science, 235, 11561167.

Herbin, J. P., Muller, C., Graciansky, P.Ch. de, Jacquin, T., Magniez-Jannin, F. \& Unternehr, P. 1987. Cretaceous anoxic events in the South Atlantic, Rev. Bras. Geoc., 17 (2), 92-99.

Jacquin, T. \& Graciansky, P. Ch. de 1988. Cyclic fluctuations of anoxia during Cretaceous time in the South Atlantic ocean. Mar. and Petrol. Geol., 5, 359-369.

Jarvis, I., Carson, G.A., Cooper, M.K.E., Hart, M.B., Leary, P.N., Tocher, B.A., Horne, D. \& Rosenfeld, A. 1988. Microfossil assemblages and the Cenomanian-Turonian (late

\section{Explanation of Plate 4 \\ All illustrations are scanning electron photomicrographs. \\ Scale bars $=100 \mu \mathrm{m}$.}

\section{Diatoms}

Figs. 1-2. Morphotype A. (Broad, thin, flattened discus; biscuit-shaped); Fig. 1, lateral view. Fig. 2, peripheral view: locality Pati 1 (lowermost Turonian).

Figs. 3-4. Morphotype B (Short, moderately thick, vertical periphery; pill-shaped); Fig. 3, lateral view, Fig. 4, peripheral view; locality Pati 1 (lowermost Turonian).

Figs. 5-8. Morphotype $C$ (Thick flattened discs; drum-like); Fig. 5. Specimen I, peripheral view; Figs. 6,7. specimen II, Fig. 6, lateral view, Fig. 7. peripheral view; specimens I \& II from well 1-US-1-SE: 336-351m (lowermost Turonian). Fig. 8, specimen III, peripheral view, from locality Pati 1 (lowermost Turonian).

Figs. 9-10. Morphotype D (Lenticular, biconvex; lentil-shaped), Fig. 9, lateral view, Fig. 10, peripheral view, locality Pati 2 (uppermost Cenomanian).

Figs. 11-12. Morphotype E (Rounded periphery, broad, moderately thick morphotype; biscuit-shaped); fig. 11, lateral view, Fig. 12, peripheral view, locality Pati 2 (uppermost Cenomanian).

Figs. 13-14. Morphotype F (Rounded periphery, short, thick morphotypes; pill-shaped); Fig. 13, lateral view, Fig. 14 peripheral view, locality Pati 2 (uppermost Cenomanian). 


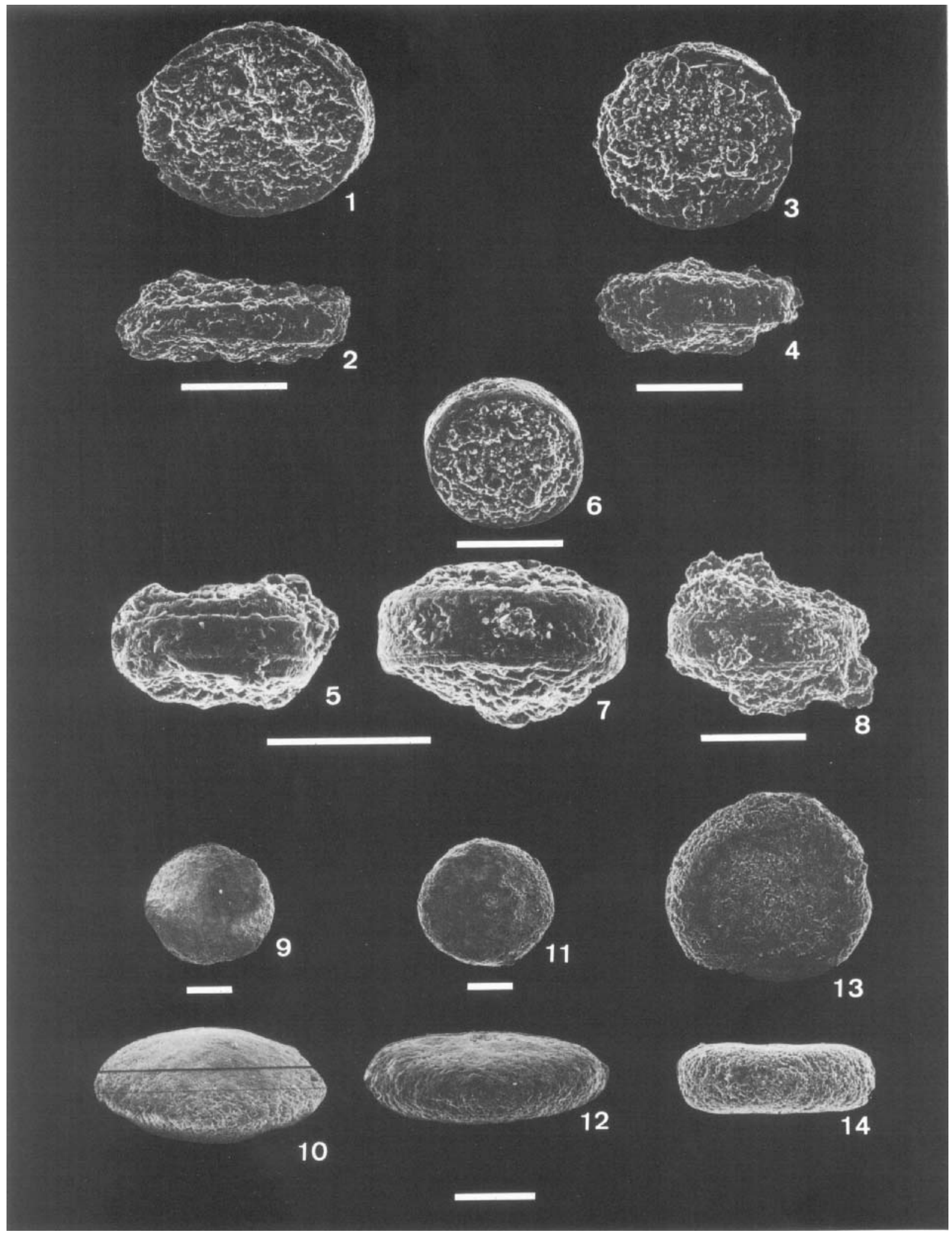


Cretaceous) oceanic anoxic event. Cretac. Res., 9, 3-103. Jenkyns, H. C. \& Winterer, E. L. 1982. Palaeoceanography of Mesozoic ribbon radiolarites. Earth Plan. Sc. Lett., Amsterdam, 60 (3), 351-375.

Katz, B. J. \& Elrod, L.W. 1983. Organic geochemistry of DSDP Site 467, offshore California, Middle Miocene to Lower Pliocene strata. Geochim. Cosmochim. Acta, 47, 389-396.

Kotzian, S. C. B.\& Eilert, V. B., 1987. Radiolários do Cretáceao "Médio" na Bacia de Campos, Brasil. X Conqr. Bras. Paleont., Anais, 2, 783-796.

Koutsoukos, E. A. M. 1984. Evolucão paleoecológica do Albiano as Maestrichtiano na área noroeste da Bacia de Campos, Brasil, com base em foraminiferos. XXXIII Congr. Bras. Geol., Anais, 2, 685-698.

Koutsoukos, E. A. M. \& Hart M. B. (in press). Cretaceous foraminiferal morphogroup distribution patterns, palaeocommunities and trophic structures: a case study from the Sergipe Basin, Brazil. Royal. Soc. Edinburgh, Trans. : Earth Sc.

Koutsoukos, E. A. M., Mello, M. R., Azambuja Filho, N. C. de, Hart, M. B. \& Maxwell, J. R. (in press.) The upper AptianAlbian succession of the Sergipe Basin, Brazil: an integrated palaeo-environmental assessment. Amm. Ass. Petr. Geol., Bull., Tulsa.

Koutsoukos, E. A. M., Mello, M. R., Azambuja Filho, N. C. de in preparation. Micropalaeontological and geochemical evidence of mid-Cretaceous hypoxic/anoxic environments in the Sergipe Basin, NE Brazil. Proceedings "Modern and Ancient Continental Shelf Anoxia" (London, 17-19th May, 1989), Spec. Pub. Geol. Soc. of London.

Kuhnt, W., Thurow, J., Wiedmann, J. \& Herbin, J. P. 1986. Oceanic anoxic conditions around the Cenomanian/Turonian boundary and the response of the biota. Mitt. Geol-Palaont. Inst. Univ. Hamburg. Hamburg, 60, 205-246.

Leckie, R. M. 1981. Mid-Cretaceous planktonic foraminiferal biostratigraphy off central Morocco, DSDP Leg 79, Sites 545 and 547.In.Rep. Deep Sea Drill. Proj., Washington, 79, 570620.

Lisitzin, A. P., 1972, In: Rodolfo, K. S., ed., Sedimentation in the World Ocean. Spec. Pub., Soc. Econ.Paleontol. Mineral., 17, $218 \mathrm{p}$.

Luyendyk, B. P. Forsyth, D. \& Phillips, J. D. 1972. Experimental approach to the paleocirculation of the oceanic surface waters. Geol. Soc. Am. Bull., New York, 83, 2649-2664.

Magniez-Jannin, F.\& Jacquin, 1988. Foraminiféres et séquences sédimentaires: vers une meilleure compréhension des environments anoxiques du Crétacé dans 1'Atlantique Sud. Rev. Paléobiol. (Benthos' 86), Vol. Spéc., 2, 297-307.

Mello, M. R. Geochemical and molecular studies of the depositional environments of source rocks and their derived oils from the Brazilian marginal basins. Unpub. Ph.D. thesis, University of Bristol.

Mello, M. R., Koutsoukos, E. A. M., Hart, M. B., Brassell, S. C. \& Maxwell. J. R,, 1989. Late Cretaceous anoxic events in the Brazilian continental margin. Org. Geochem., 14 (5), 529 . 542.

Miskell, K. J., Brass, G. W. \& Harrison, C. G. A. 1985. Global patterns in opal deposition from Late Cretaceous to Late Miocene. Am. Assoc. Petrol. Geol., Bull., Tulsa, 69, (6), 9961012.

Moore, T. C., Jr. 1973. Radiolaria from Leg 17 of the Deep Sea Drilling Project. In. Rep. Deep Sea Drill.Proj., Washington, 17, 979-869.

Ojeda, H. A. O. \& Fugita, A. M. 1976. Bacia Sergipe/Alagoas:
Geologia regional e perspectivas petroliferas. XXVIII Congr. Bras. Geol., Anais, Porto Alegre, 1, 137-158

Pessagno, E. A., Jr. 1963. Cretaceous Radiolaria from Puerto Rico. Micropaleont., New York, 9 (2), 197-214, pls. 1-7.

Pessagno, E. A., Jr. 1971. Jurassic and Cretaceous Hagiastridae from the Blake-Bahama Basin (Site 5A, Joides Leg 1) and the Great Valley Sequence, California Coast Ranges. Bull. Am. Paleont., Ithaca, N.Y., 60 (264), 5-83.

Pessagno, E. A., Jr. 1972a Cretaceous Radiolaria. Part I: the Phaseliformidae, new family, and other Spongodiscacea from the Upper Cretaceous portion of the Great Valley sequence. Bull. Am. Paleont., Ithaca, N.Y., 61, (270), 269 280.

Pessagno, E. A., Jr. 1972b. Cretaceous Radiolaria. Part II. Pseudoaulophacidae Riedel from the Cretaceous of California and the Blake-Bahama Basin (Joides Leg I). Bull. Am. Paleont., Ithaca, N.Y., 61 (270), 283-328.

Pessagno, E. A., Jr. 1973. Upper Cretaceous Spumellariina from the Great Valley Sequence, California Coast ranges. Bull. Am. Paleont., Ithaca, N.Y., 63 (276), 49-102.

Pessagno E. A., Jr. 1976. Radiolarian zonation and stratigraphy of the Upper Cretaceous portion of the Great Valley Sequence California Coast Ranges. Micropaleont., Spec. Pub., New York, 2, 67p.

Pessagno, E. A., Jr. 1977. Radiolaria in Mesozoic stratigraphy. In: Ramsay, A.T.S. (ed. ), Oc. Micropalaeont., London, 2(Ch. 9), 913-950.

Renz, G. W. 1974. Radiolaria from Leg 27 of the DSDP. In. Rep. Deep Sea Drill. Proj., Washington, 27, 769-841.

Riedel, W. R. \& Sanfilippo, A. 1974. Radiolaria from the southern Indian Ocean, DSDP Leg 26. In. Rep. Deep. Sea Drill. Proj., 26, 771-813.

Savin, S. M. 1977. The history of the earth's surface temperature during the last 100 million years. In: Donath, F. A., Stehli, F. G. and Wetherill, G. W., eds. Earth Plan. Sc. Lett. Annual rev., Amsterdam, 5, 319-355.

Schlanger, S. O. \& Jenkyns, H. C. 1976. Cretaceous oceanic anoxic events: causes and consequences. Geol. Mijnbouw. 55, (3-4), 179-184.

Schlanger, S. O., Arthur, M. A., Jenkyns, H. C. \& Scholle, P. A. 1987. The Cenomanian-Turonian oceanic anoxic event, I. Stratigraphy and distribution of organic-rich beds and the marine ${ }^{13} \mathrm{C}$ excursion. In. Brooks, J. \& Fleet, A.J. (Eds.), Marine Petroleum Source Rocks, Geol. Soc., Spec. Publication, 26, 371-400, Blackwell Scientific Publications.

Thurow, J. \& Kuhnt, W., 1986. Mid-Cretaceous of the Gibraltar Arch area. In: Summerhayes, C. P. \& Shackleton, N. J., eds, North Atlantic Palaeoceanography, Spec. Publ. Geol. Soc: London Blackwell.

Thurow, J., Kuhnt, W. \& Wiedmann, J. 1982. Zeitlicher und paläogeographischer Rahmen de Phthanit- und Black ShaleSedimentation in Marokko. N.Jb. Geol.Paläont. Abh., 165, 147-176.

Viviers, M. C., 1986. Bioestratigrafia e evolucão paleoambiental do Meso-Neocretáceo da Bacia de Santos, brasil. XXXIV Congr. Bras. Geol., Anais., 1, 50-64.

Wall, J. H. 1975. Diatoms and radiolarians from the Cretaceous System of Alberta - a preliminary report. In. Caldwell, W.G.E. (Ed.), The Cretaceous System in the Western Interior of North America, Geol. Ass. Canada, Spec. Paper, 13, 391410.

de Wever, P. 1983. Radiolarian preservation in geologic sequences, Am. Ass. Petr. Geol., Bull. (Convention Issue, Abstracts), Tulsa, 67 (3), 450. 
Wolfart, R. 1982. Cretaceous radiolaria from the northwest African continental margin. In von Rad, U., Hinz, K., Sarnthein, M. \& Seibold, E. (Eds.), Geology of the Northwest African Continental Margin, Springer-Verlag, Berlin, 354365.

Zittel, K. A. 1876. über einige fossile Radiolarien aus der norddeutschen Kreide. Zeit, Deutsche Geol Ges., Zeitschr., 28, 75-86, pl. 2.

\section{APPENDIX}

DESCRIPTIONOF LOCALITIES AND WELL SECTIONS

I - Locality Data (Cenomanian-Turonian)

The following information is provided for each outcrop:

(1) Cross-reference with toponyms and respective locality numbers documented by Bengtson (1983), p. 63-71), for the Cenomanian-Coniacian sections.

(2) Lithostratigraphic unit.

(3) Ammonite (inferred after Bengtson, op.cit. ) or foraminiferal biozone and assigned stage.

(4) Geographic coordinates, according to the international 'Universal Transverse Mercator' (UTM) grid system (starting point at the central meridian $39^{\circ}$ of Greenwich).

Locality A: (1) Itaporanga 2-3. (2) Continguiba Formation, Sapucari Member. (3) Graysonites Zone; lower Cenomanian. (4). UTM $8783700 \mathrm{~N} / 684925 \mathrm{E}$.

Locality B: (1) Itaperoá 3. (2) Cotinguiba Formation, Sapucari Member. (3) Graysonites Zone; lower Cenomanian, (4) UTM $878540 \mathrm{~N} / 686300 \mathrm{E}$.
Locality C: (1) Pati 2. (2) Cotinguiba Formation, Aracaju Member. (3) Globigerinelloides bentonensis (Morrow)Hedbergella $(W)$. aprica (Loeblich \& Tapan) Oppel-zone; uppermost Cenomanian. (4) UTM 8803100 N/ 692875 E.

Locality D: (1) Pati 1. (2) Continguiba Formation, Aracaju Member. (3) Pseudotissotia Zone; lowermost Turonian. (4) UTM $8802900 \mathrm{~N} / 693350 \mathrm{E}$.

Locality E: (1) Aroeirinha 4. (2) Cotinguiba Formation, Sapucari Member. (3) Pseudotissotia Zone: lowermost Turonian. (4) UTM $8802400 \mathrm{~N} / 693800 \mathrm{E}$.

Locality F: (1) São Pedro 5. (2) Cotinguiba Formation, Sapucari Member. (3) Hoplitoides Zone; lower-Upper Turonian. (4) UTM $8800085 \mathrm{~N} / 696370 \mathrm{E}$.

Locality G: (1) Mata 1. (2) Cotinguiba Formation, Sapucari Member (3) Subprionocyclus Zone; uppermost Turonian. (4) UTM 8799975 N/ 701375 E.

Locality H: (1) Pedra Branca 17. (2) Cotinguiba Formation, Sapucari Member. (3) Pseudotissotia Zone / Hoplitoides Zone; lower Turonian. (4) UTM 8805710 N/ $703100 \mathrm{E}$.

\section{II - Location of Borehole Sites (Onshore Area)}

Well 1-CA-1-SE Geographic coordinates: Lat. 10 54' 30" SLong. $37^{\circ} 07^{\prime} 45^{\prime \prime} \mathrm{W}$.

Well 1-CRL-1-SE Geographic coordinates: Lat. $10^{\circ} 59^{\prime} 45^{\prime \prime} \mathrm{S}-$ Long. $37^{\circ} 09^{\prime} 00^{\prime \prime} \mathrm{W}$.

Well 1-US-1-SE Geographic coordinates: Lat. $10^{\circ} 50^{\prime} 10^{\prime \prime} \mathrm{S}$ Long. $37^{\circ} 12^{\prime} 00^{\prime \prime} \mathrm{W}$. 